\title{
INFORMATION SYSTEMS IN WESTERN AUSTRALIAN UNIVERSITIES
}

\section{Professor Craig Standing}

\author{
School of Management Information Systems \\ Edith Cowan University. \\ c.standing@ecu.edu.au
}

\section{Professor Janice Burn}

\author{
School of MIS \\ Edith Cowan University \\ Perth, WA \\ j.burn@ecu.edu.au \\ Dr. Chad Lin \\ School of Management Information Systems \\ Edith Cowan University \\ c.lin@ecu.edu.au
}

\begin{abstract}
The authors of this paper examine the current state of the development of Information Systems (IS) teaching and research within Western Australia (WA). A brief overview of the WA environment is followed by an exploration of teaching and research in the four main Universities. This is examined against the framework for the study and, in particular, the impact of social processes (Ariav et al, 1987; Klein et al, 1991) and local contingencies (Culnan et al, 1993; Checkland and Howell, 1998), which are found to be of relevance to historic developments.
\end{abstract}

\section{INTRODUCTION}

Western Australia (WA) is the largest state in Australia, spanning $2400 \mathrm{~km}$ from North to South and encompassing 2.5 million square kilometres. The State is fairly isolated from the rest of Australia and still maintains something of a 'frontiersman' mentality. This is compounded by the low population, with only 2 million inhabitants, approximately $73 \%$ of whom live in the capital city of Perth, which has a current population of 1.5 million. The rest of WA is populated by small country towns which are typically remote from other centres and many of which lack basic infrastructure such as health and education services. In particular, broadband access is variable and information and communication technology services can be poor. 
The capital city of Perth has the dubious reputation of being the most remote city in the world, being as close to Singapore as it is to Sydney and a five hour flight from either. This has compensations since Perth is on the same time zone as the Asian centres of Hong Kong and Singapore and hence attractive for international collaboration in business and indeed in education. However, the remoteness of the state has meant that few businesses headquarter in WA and, as such, collaboration with local industry becomes a problem since they tend to favour states where they are headquartered. The State also derives most of its revenue from the minerals and oil industries, with the majority of large companies associated with mining in some form.

These location factors have impacted on the development of WA Universities, since while all four public universities are based in Perth, they all have a remit to service the whole State and so typically have remote campuses across WA. Additionally, all universities have substantial external offerings which initially targeted the distant WA population but now recruit from a global community. WA population has remained fairly stable but is now forecast to grow; however, the growth in University students has come largely from out of State enrolments and specifically from Asia.

\section{Overview of WA Universities}

The five Universities in WA (ordered by number of enrolments from largest) are:

Curtin University of Technology

Edith Cowan University (ECU)

The University of Western Australia (UWA)

Murdoch University

Notre Dame University

Table 1 shows overall enrolment figures for 2004 and comparative statistics from DEST Selected Higher Education Statistics.

\begin{tabular}{|l|c|c|c|c|c|}
\hline University & Total & \% Overseas & \% Postgrad & \% Research & $\begin{array}{c}\text { \% School } \\
\text { leavers }\end{array}$ \\
\hline Curtin & 36,064 & 39.7 & 22.2 & 4.3 & 43.1 \\
\hline ECU & 23,887 & 17.8 & 19.6 & 2.6 & 33.1 \\
\hline UWA & 16,806 & 17.7 & 25.8 & 11.3 & 75.0 \\
\hline Murdoch & 12,655 & 17.5 & 17.8 & 6.5 & 34.9 \\
\hline Notre Dame & $3000+$ & N/A & N/A & N/A & N/A* \\
\hline
\end{tabular}

* Notre Dame University is a private Catholic University

Table 1 shows overall enrolment figures for 2004 and comparative statistics.

A brief historical overview of these five helps to explain the particular unique focus of each institution and the positioning of Information Systems within the Universities.

\section{University of Western Australia}

UWA was the State's first university, established in 1911, and is a member of the 'Group of 8' referring to the eight most prominent research oriented Universities in Australia, often referred to as the 'Sandstone Universities'. UWA has proportionately the highest intake of school-leavers nationally (national average was $44.3 \%$ ) and consistently recruits over $80 \%$ of the State's top $5 \%$ of School leavers. The Good Universities Guide states "UWA has more young, bright full-timers than 
any other University in the country - - it is at the top of the WA academic totem pole”. Typically all undergraduate students would be full-time. With this profile of students, the most popular disciplines are the traditional ones and Information Systems plays only a supporting role. Originally IS was part of the Department of Information Management and Marketing (DIMM) founded in 1993. A full major of IS units was first offered in 1998. The IM discipline group is now embedded within the School of Economics and Commerce; itself one of two schools in the UWA Business School.

\section{Curtin University of Technology}

Curtin University of Technology is WA's largest university and evolved from the Western Australian Institute of Technology (WAIT) in 1986. WAIT itself had been created in 1966 from the former Perth Technical College, which in 1969 also merged with the WA School of Mines, the Muresk Agricultural College and Schools of Physiotherapy and Occupational Therapy. Between 1966 and 1976, student enrolments expanded from 2,000 to over 10,000 and WAIT consolidated around three large schools of:

- Health Sciences

- Business and Administration

- Arts and Architecture

WAIT's Business School was the largest in Australia and, in 1975, the School of Computing and Quantitative Studies was formed with a prime focus on IS. In 1986, when Curtin University was formed, the School was renamed the School of Information Systems and remains within the Business Faculty. There is a separate School of Computer Science in a different Faculty.

Curtin has a main campus and two additional metropolitan campuses in Perth and regional campuses in Kalgoorlie and Northam. In addition, they have an off-shore campus in Sarawak Malaysia and a new campus in Sydney Central Business district. Curtin has 13 Education centres within WA and 15 overseas education centres.

Curtin has the largest international student population in the State with around 40\% - high by national standards. These students will typically be full-time and their Australian counterparts a mix of full-time and part-time.

\section{Edith Cowan University}

ECU was granted university status in 1991 and evolved from a number of Education colleges formed as early as 1902. ECU remains the State's major provider of teacher education. While the State's second largest university, it actually has the largest enrolment of WA students. ECU focuses on the service professions and defines its particular strengths as:

- Education

- Nursing

- Business

- Computing

- Communications

- Creative and Performing Arts 
Information Systems was part of the School of Information Systems and Management Science in the 1980s and became the Department of Management Information Systems in 1988 within the Faculty of Business. A separate School of Computer Science is in a different Faculty.

ECU had many campuses but has recently consolidated and now has its main campus 28km north of the city centre in Joondalup - one of the fastest growth areas in Australia. They have a second city campus and a regional campus at Bunbury in the south.

Over $50 \%$ of the students at ECU are 'mature' entrants and typically part-time students. With this profile IS students would normally come from within the IT industry - as IT has suffered a decline so the student population has declined.

\section{Murdoch University}

Murdoch University was formally constituted as WA's second University in 1973 and, while a research-based university, it has a very strong emphasis on good teaching. Information Systems has had a chequered history as part of an Information Technology group. Originally the Department of IT was part of the School of Mathematics, Business and Sciences and then in 1997 IT was moved to Business Information Technology and Law. In 2003, the School of Information Technology was moved into the Division of Arts.

Murdoch University has three campuses with two regional campuses and one city campus.

\section{Notre Dame University}

The University of Notre Dame was founded in 1990 and is a private Catholic University. Despite its small size it has eight colleges and the School of Information Technology resides within the College of Science and Technology. Interestingly, all the courses offered in IT are offered in online mode and the university spawned a separate company to promote the development of such online material. There is no IS group as such and the IT school has only two permanent staff members.

For the purposes of this study only the public Universities are considered in depth. Notre Dame does not have an Information Systems Department.

\begin{tabular}{|l|l|c|c|c|}
\hline University & Unit & IS Staff & IS UG Students & IS PG students \\
\hline Curtin & School of IS & 24 & $\sim 160$ & $\sim 200$ \\
\hline ECU & School of MIS & 18 & $\sim 150$ & $\sim 110$ \\
\hline UWA & School of IT & 7 & $\sim 100$ & $\sim 25$ \\
\hline Murdoch & School E \& C & 8 & $\sim 70$ & $\sim 10$ \\
\hline
\end{tabular}

Table 2: an overview of the approximate numbers of IS staff and student numbers within the four public universities.

Within these staffing numbers, Curtin University has three IS Professors, Edith Cowan has three IS Professors and UWA and Murdoch, no IS Professors. 


\section{THE STUDY}

Interviews were conducted with senior academics at the four public universities during April and May 2005. The data summarised below represents the picture at that time. It should be noted, however, that in all cases, numbers were falling and continue to fall, with a severe decline in student enrolments and commensurate reduction in staff numbers. The dramatic upswings and downswings in student numbers in the IS discipline over the years would suggest that the 'discipline' is very tightly aligned with the perceived industry needs of the moment rather than being viewed as a substantive 'professionalised’ academic discipline in its own right (Ruscio, 1987).

\section{Courses}

Curtin University cover the whole spectrum of IT, EC and IS with a recent emphasis towards some of the more technical IS subjects; ECU focuses on the business applications of IS, EC and IM with a specialisation in ERP at Post Graduate level; UWA clearly identifies Information Management as their specialisation with a focus on support for other discipline majors such as accounting and marketing and Murdoch focus on the more technical aspects of IS such as IS Development and use of Multimedia. ECU is also targeting a new market with a Masters Degree in Strategic Project Management which they hope will appeal to a broader market base.

\begin{tabular}{|l|l|l|}
\hline University & \multicolumn{1}{|c|}{ UG Courses } & \multicolumn{1}{c|}{ PG Courses } \\
\hline Curtin & $\begin{array}{l}\text { Bachelor of Commerce (IS) } \\
\text { Bachelor of Commerce (IT) } \\
\text { Bachelor of Commerce (EC) }\end{array}$ & $\begin{array}{l}\text { Grad Dip/Certificates } \\
\text { Post Grad Dip/Certificates } \\
\text { Master (IS) } \\
\text { Master of Commerce } \\
\text { PhD }\end{array}$ \\
\hline ECU & $\begin{array}{l}\text { Bachelor of Business (IS) } \\
\text { Bachelor of Business (EC) } \\
\text { Bachelor of Business (IM) } \\
\text { Bachelor of IS }\end{array}$ & $\begin{array}{l}\text { Grad Dip/Certificates (IS, EC, ERP) } \\
\text { Master (IS) } \\
\text { Master Strategic Project Management } \\
\text { DBA (IS) } \\
\text { PhD }\end{array}$ \\
\hline UWA & Bachelor of Commerce (IS) & $\begin{array}{l}\text { Master Information Management } \\
\text { Master of Commerce (IM) } \\
\text { PhD }\end{array}$ \\
& \multicolumn{2}{|l}{} \\
\hline Murdoch & $\begin{array}{l}\text { Bachelor of Science (IS Dev) } \\
\text { Bachelor of Science (BIS) } \\
\text { Bachelor Science (Multimedia) } \\
\text { Bachelor of Science in IS }\end{array}$ & $\begin{array}{l}\text { Masters IS } \\
\text { PhD }\end{array}$ \\
&
\end{tabular}

Table 3 shows the wide variety of courses offered across all four Universities.

Despite some low enrolments in the UG and PG programmes, PhD programmes continue to thrive in all four IS groups with a total of around 60 Doctoral students by research. In addition ECU offers a unique DBA programme in IS. This is a partially taught programme with a shorter thesis component and has a further 20 doctoral students mainly drawn from senior managers in the WA community. In general enrolments in general degrees such as Bachelor of Business with IS specialisations remain fairly steady but enrolments on specialist IS degrees are dropping radically. 
Interest in multimedia has declined significantly and Electronic Commerce no longer holds the appeal it once did. International recruitment has had a substantial decline impacting on the postgraduate market.

\section{RESEARCH}

Research focus within the four Universities is also very different and this may be one of the reasons that all interviewees identified the low level of collaboration between WA Universities. Indeed, at the time of writing there were no joint projects and staff in each University seemed unfamiliar with research being conducted in other WA institutions. Funding was variable with the onus on staff to generate funding through successful grant applications both internally or externally or through collaborative partnerships with industry. Curtin has an industry sponsored Professor which comes with considerable prestige in addition to research funds. Research output also varied considerably. At UWA research activity of staff was largely interdisciplinary and with a relatively low proportion contributing to strictly IS-related research to a high output overall at ECU with around $90 \%$ of staff research active. Curtin followed the more typical path with $20 \%$ of staff providing $80 \%$ of output. It was stated that Curtin had shifted emphasis towards teaching over research in recent years. Identified themes for ongoing research are shown in Table 4.

\begin{tabular}{|c|c|c|c|}
\hline University & Themes & Groups & Funding \\
\hline Curtin & $\begin{array}{l}\text { Technology Adoption } \\
\text { Information Technology } \\
\text { Management } \\
\text { Health Informatics } \\
\text { Relational Ontology } \\
\text { Worldwide Databases } \\
\text { Grid Supercomputing } \\
\text { Electronic Commerce } \\
\text { Soft Systems Methodology }\end{array}$ & $\begin{array}{l}\text { Individuals }+\mathrm{PhD} \\
\text { groupings } \\
\text { Professors }\end{array}$ & $\begin{array}{l}\text { Grant based }+ \\
\text { Research } \\
\text { Performance } \\
\text { Index funding } \\
\text { system }\end{array}$ \\
\hline$\overline{\mathrm{ECU}}$ & $\begin{array}{l}\text { Electronic Markets } \\
\text { Collaborative Commerce in } \\
\text { SMEs } \\
\text { IS Evaluation } \\
\text { IS in Construction Industry } \\
\text { IS Education and IS in } \\
\quad \text { Education }\end{array}$ & $\begin{array}{l}5 \text { formal research } \\
\text { groups led by the } \\
\text { Professors/Ass Profs } \\
+ \text { individual }\end{array}$ & $\begin{array}{lr}\text { Grant } & \text { based }+ \\
\text { Research } & \text { Activity } \\
\text { Index } & \text { funding } \\
\text { system } & \end{array}$ \\
\hline UWA & $\begin{array}{l}\text { Knowledge Management } \\
\text { Virtual communities } \\
\text { e-Government } \\
\text { Transport modelling } \\
\text { Compliance monitoring systems }\end{array}$ & $\begin{array}{l}\text { Individuals } \\
\text { and } \\
\text { interdisciplinary and } \\
\text { inter-faculty } \\
\text { collaborations }\end{array}$ & $\begin{array}{l}\text { Grant-based and } \\
\text { Individual } \\
\text { research support } \\
\text { from School funds }\end{array}$ \\
\hline
\end{tabular}




\begin{tabular}{|l|l|l|l|}
\hline Murdoch & Human Factors in IS & Individuals & $\begin{array}{l}\text { Grant based + } \\
\text { individual } \\
\text { Knowledge Management }\end{array}$ \\
& e-learning & & $\begin{array}{l}\text { allocation from } \\
\text { School }\end{array}$ \\
& Decision support & & \\
\hline
\end{tabular}

Table 4 Research Themes

Curtin and ECU both operate a research performance monitoring scheme which is directly linked to research funding (Curtin University - Research Performance Index, ECU - Research Activity Index). In this way staff are rewarded with a \$ value applied to the number of points they have generated towards the research assessment quantum. This scheme provides considerable incentive for staff to become productive but can favour quantity over quality. However, at ECU the recent trend has been to decrease the funding per point being allocated to staff and to the use the money to provide competitive internal research grants.

All four universities support both qualitative and quantitative research and employ multi-methods. Case studies and interpretive research were commonly applied. The overall research picture in WA fits closely with the view of a 'Fragmented Adhocracy' (Whitley, 1984; Culnan et al, 1993; Checkland and Holwell, 1998) with low researcher mutual dependency and very different contributions from each of the four universities reflecting local political pressures from within their different institutions but also from within the State where all four compete for highly limited funding.

\section{IS LEADERSHIP}

The particular environment of WA has strongly influenced IS leadership since West Australians are often loath to leave the State because of the rather laid back life style and tropical weather, giving a core academic staff remaining fairly static over the long term. In addition West Australia is seen as a desirable location for international immigrants and hence the state attracts a fair share of international academics. It is rare to see Australian academics from the Eastern states choose to relocate west. This has had two consequences, WA academics have had to strive for excellence within the Australian arena; WA has gained an international profile through its international academics. Richard Watson (originally WA home grown), Bob Galliers and Janice Burn have all contributed to the development of IS within the state, coming from an international perspective, and West Australians Graham Pervan and Bernie Glasson have had significant input both nationally and internationally. All six current Professors at Curtin and ECU are well known researchers with national and international reputations.

Interviewees stressed the real need for IS leadership and active involvement in IS research by the Professoriate. IS groups without a professor tended to have significantly lower profile in their home university.

\section{CONCLUSIONS}

The main IS strength in WA lies in Curtin and ECU, where separate IS Schools have been in existence for over 30 years. In 2007, the IS School at ECU will merge with the School of Management to form a new School but it will still retain its identity as a discipline. IS is recognised as a discipline in UWA and Murdoch but as a sub-set of other disciplines and has a somewhat lower 
status in these two institutions. Different value systems and funding models inhibit collaboration between the four institutes. In 1998 Curtin took the lead to organise the WA workshop in IS research (WAWISR) and this was repeated each year, hosted by each university in turn until 2001, when enthusiasm to organise it was exhausted. Sadly, one of the reasons for this may be the increased emphasis on recognised research output, lessening the motivation for activities which would solely be regarded as community building. Similarly, in 1999 ECU ran the first Working for e-Business (WeB) conference based in Perth and continued to organise this until 2004. This conference attracted some local attendees but many more came from across Australia to forge national collaborative links.

With respect to the development of IS as a discipline, social processes and local contingencies seem to have had considerable impact. WA is the most distant state in Australia and hence looks inward to local industry for direction but also outwards from Australia to forge international reputations. Mechanisms of control are very much still in a developmental mode although this applies to the country as a whole, with IS representation on the national research funding body - the Australian Research Council (ARC) only being achieved in 2000 with the appointment of Professor Janice Burn as the IS discipline representative on the ARC research panel for Mathematics Information and Computer Sciences. The core body of knowledge taught at each of the four universities tends to reflect local allegiances with industry, services and professions and varies in line with local developments and needs rather than necessarily responding directly to demands from within the discipline itself.

All interviewees commented on the decrease in numbers in IS and diminishing staff numbers, which suggests that the picture painted in this study may be a very different one over the next few years. It was also interesting to note that IS was seen to be a discipline grouping which could easily be transposed from within one discipline grouping to another, with residual homes having been found in Business, Sciences, Mathematics and even Engineering at one time or another across the four institutes. From the WA perspective it would appear that IS is still 'a perspective' (Fitzgerald, 2003) rather than a discipline and a perpetually shifting perspective at that.

\section{REFERENCES}

Ariav, G., de Sanctis, G. \& Moore, J. (1987) “Competing Reference Disciplines for MIS Research”, Proceedings of the Eighth International Conference on Information Systems, Pittsburgh, pp 455-458.

Checkland, P. \& Holwell, S. (1998) Information Systems and Information Systems - Making Sense of the field. Wiley and Sons, Chichester.

Culnan, M. J., Swanson, E. B. \& Keller, M. T. (1993) "MIS Research in the 1980s: Shifting points of work and reference", Proceedings of the $26^{\text {th }}$ Hawaii International Conference on Systems Sciences, Vol 3, pp 597-606.

Fitzgerald, G. (2003) "Information Systems: A subject with particular perspective, no more, no less”, European Journal of Information Systems, Vol 12 No 3, pp 225-229.

Klein, H. K., Hirshheim, R. \& Nissen, H. (1991) “A Pluralist Perspective of the Information Systems Research Arena”, In Nissen, H. E., Klein, H. K. and Hirshheim, R. (eds). Information Systems Research: Contemporary Approaches and Emergent Traditions, Elsevier, Amsterdam. 
Ridley, G. (2006) “Characterising Information Systems in Australia: A Theoretical Framework”, Australasian Journal of Information Systems, Vol 13 No 3, pp. 38-60.

Ruscio, K. (1987) "Many Sectors, Many Professionals”, In B. Clarke (Ed). The Academic Profession, University of California Press.

Whitley, R. (1984) “The Development of Management Studies as a Fragmented Adhocracy”, Social Science Information, Vol 23 No 4/5, pp 775-818.

\section{ACKNOWLEDGEMENTS}

Thanks are due to the following interviewees:

Professor Janice Burn, ECU

Dr Nick Letch, UWA

Professor Graham Pervan, Curtin

Professor Craig Standing, ECU

Dr Fay Sudweeks Murdoch

Mr Danny Toohey, Murdoch

\section{THE AUTHORS}

Janice Burn was appointed Foundation Chair of Information Systems at Edith Cowan University in Perth in 1997. She had previously held positions in Hong Kong, Canada and UK. Her research interests centre on the strategic use of IS and its impact on organisational effectiveness in a wide variety of global contexts. Janice has published extensively in these areas and now enjoys a well earned semi-retirement in the South of France where she continues to supervise her Doctoral students as a virtual Professor.

Craig Standing is Professor of Strategic Information Management and Head of School in the School of Management Information Systems at Edith Cowan University, Australia. His current research interests are in the areas of electronic markets and mobile commerce. He has published in the European Journal of Information Systems, IEEE Transaction on Engineering Management, Information \& Management and European Journal of Operational Research.
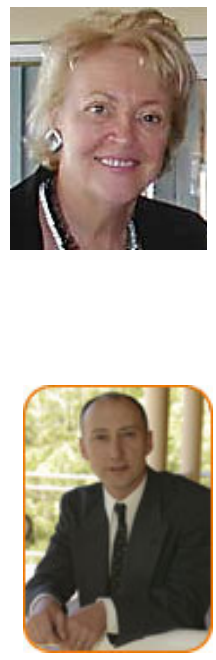

Dr Chad Lin is a Post-Doctoral Research Fellow in School of Management Information Systems at Edith Cowan University in Australia. He has published many international research articles on a range of topics including outsourcing, e-commerce, IS/IT adoption, and evaluating the effectiveness of IS/IT.

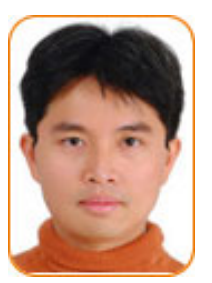


